\title{
Common Grammatical Errors in Written Discourse of EFL Iraqi Learners
}

\author{
Doaa Faris Al-shammery' \\ Azar Huesiani" \\ Hesamoddin Shahriari"l'
}

\begin{abstract}
The current study was an attempt to explore the common grammatical errors in written discourse of EFL Iraqi learners across gender. To this end, five male and five female Iraqi EFL academic learners with the same proficiency level were randomly selected. The participants were supposed to write a descriptive composition on a common topic. Findings showed Iraqi EFL learners made various errors in the following categories including tenses, prepositions, articles, active and passive voice, verbs and morphological error. It has been found that most of these errors caused by the effect of grammatical and linguistic system of participants' first language on their written production of the target language.
\end{abstract}

Keywords: Grammatical errors; Written discourse; EFL Iraqi Learners

\footnotetext{
' Department of English Language and Literature, Faculty of Letters and Humanities, Ferdowsi University of Mashhad, Mashhad, Iran- d.al.shammery@gmail.com

"Department of English Language and Literature, Faculty of Letters and Humanities, Ferdowsi University of Mashhad, Mashhad, Iran - Azar. huesiani@um.ac.ir

I'Department of English Language and Literature, Faculty of Letters and Humanities, Ferdowsi University of Mashhad, Mashhad, Iran - h.shahriari@um.ac.ir
} 


\section{Introduction}

According to Crompton (2011), learning the complexity of grammar through writing has continuously remained a problem to many students especially the second and foreign users of English. In majority of the countries all over the world, the English variations - British and American are regarded as models, and the choice of usage greatly depended on whether the country was colonized by either the Americans or the British people. Commonly, even minor errors in grammar cripple the meaning of the communication being engaged into. When errors persist, misunderstanding comes in, causing delays in comprehension, that further results to failure in the part of the sender as he sends the intended message to the receiver. As a result, the teachers' effectiveness and efficiency are being doubted. Though intelligibility and comprehensibility of what is written are to be primarily observed over grammatically accurate phrases and sentences, the need of mastering the complexity of grammar must be addressed especially that English has been globally used in almost all transactions. Consequently, the ability to use English correctly and acceptably has now become an edge over others.

Many Arab researchers in context of foreign language teaching had focused on the learners' errors in different context (e.g. Rababah, 2005; Al-Bayati, 2013; Humeid \& Altai, 2013). These studies deal with difficulties that Arab learners encounter in their English learning process. For example, Rababha (2005) argued, "Arab learners of English encounter problems in both speaking and writing" (p. 22). Rababah (2005) had analyzed these difficulties by indicating the kind of errors associated with both language use and language usage. In this regard, Corder (1973) argued that the study of errors is part of the investigation of the process of language learning since these errors provide us with clear picture of the linguistic development that learner undergo and give us indicator on what are the learning strategies employed within this learning process.

\subsection{Statement of the Problem}

Grammar of a language is one of the key factors to successful writing. Despite communication skills (CS) being taught in the country for many years, many people 
particularly where graduates go to work after graduations, complain that many graduates cannot communicate effectively in written or spoken English. It seems, the goals for teaching SC have not been attained since then. Mwakapina (2011) argues that most of the students before graduation and after graduation still manifest low communicative abilities in English as a Second Language (L2). Similarly, Jordan(1997), Johns (1997), Carson (1997), Prior (1998) and Hintel, (2002a) argue that despite students having studied English as well as academic writing in English in their native and in English speaking countries, non -native speaking students experience a great deal of difficulty in their studies at college and university levels in English speaking countries. Therefore, the problem is inherent to both non- native students who study in their native countries, and even those who go to study abroad.

Many studies have established strong positive linkages between students' academic performance and grammar and writing proficiencies (Johns, 1997; Jordan, 1997; Lee \& Schallert, 1997; Byrd \& Reid, 1998; Zhou, 2009). Given the overwhelming assumption that undergraduate students in the country, even after having undergone training in $\mathrm{CS}$, many cannot communicate effectively neither in spoken nor in written English. This study intended to address the matter scientifically by examining the common grammatical errors made by Iraqi learners in their written discourse.

\subsection{Significance of the Study}

The significance of this study stemmed from fact that by revealing the grammatical errors that Iraqi learners commit during writing production, the researcher would gain a significant insight on what are the strategies those Iraqi learners employ in their writing to acquire English language. Moreover, these errors made from the context of this study might work as a diagnostic tool in order to uncover the main grammatical problems that Iraqi learners face in their writing production so that these errors could be the focus of teaching English language for Iraqi learners in general. Moreover, from pedagogical contribution, this study would provide teachers of English as a foreign language in Iraq with the information concerning Iraqis' difficulties at different stages in their second language acquisition process so that appropriate courses could be designed and new teaching materials could be constructed for future teaching. Thus, the current study proposed the following questions: 
RQ1. What are the common grammatical errors committed by Iraqi learners in written discourse?

RQ2. Is there any significant difference between male and female EFL Iraqi learners in terms of the grammatical errors made in written discourse?

\section{Review of Literature}

In recent years there have been a growing interest in error analysis as an important branch in the rapid expanding field of applied linguistic (Tushyeh, 2010). According to Dulay et al. (1982), error analysis is a technique that concerns with almost all errors made by second language learners including those resulting from the first language learning (i.e. interlingual factors) and those which are not traced to the learners native language (i.e. intralagual factors). Corder (1981) argued that these errors are important in three ways for teacher first as they shed light on how learners learn the second language and the strategies they employed in order to learn. Second, these errors are important for teachers as indicator of learning. And finally they are important for learners themselves, as these errors are indications of hypothesis testing by the learners about second language.

As a result, many researchers had examined these errors in different educational context (e.g. Abushihab, El-Omari \& Tobat, 2011; Tahaineh, 2010; Rababah, 2003; Al-Bayati, 2013; Humeid \& Altai, 2013; Yahya, 2007; Ariff \& Mugableh, 2013). For example, Abushihab et al. (2011) analyzed the corpus of written discourse of 62 Jordanian EFL students in the department of English literature and translation at Alzaytooneh Private University of Jordan. This study was conducted in order to investigate and classify the grammatical errors that those students commit in their writing production. Results demonstrated students' most recurring errors were morphological errors, articles, verbs, active and passive and tenses. Moreover, results indicated that the highest category of errors was the errors of prepositions that comprised $26 \%$ of the total errors.

In this line of research, Al-Bayati (2013) had examined the grammatical errors that Iraqi students of Department of English language/ college of Arts at University of Kufa. However, it is worth mentioning here that this study was limited to the errors in the use of 
prepositions only and other grammatical errors were left investigated. Al-Bayati (2013) analyzed a total number of 32 students' final examination copybooks in literacy course (i.e. Novel and Drama) based on Quirk's (1985) comprehensive grammar model. Results indicated that three errors were emerged in the context of this study namely preposition omission, substitution, and addition. That is, students tend to use proper preposition if equivalent was find in their mother tongue, select the improper prepositions if equivalents are not used in in their mother tongue, and omit prepositions if equivalents are not required in their mother tongue.

Furthermore, Al-Buainain (2010) addressed the problem that students face constantly in department of English at Qatar University in their writing course. This study examined 40 exams scripts collected from those students during their first writing course in university. This study was based on error analysis techniques are proposed by Corder (1974). Data analysis showed that students' errors are systematic and classifiable to include errors in verbs, relative clauses, articles, fragments, noun modifiers, countable and uncountable nouns, and prepositions.

Hintel (2002) targeted at techniques for teaching L2 writing, grammar and lexis that can inform L2 instruction, and effectively targeted L2 areas that require substantial improvement. On the other hand, Hintel (2013) focused on specific grammar constructions and their lexical elements that are critical in teaching L2 academic writing. In the same way, Lynch and Anderson (2013) provides the key areas of English grammar that one needs to master, in order to express oneself correctly and appropriately in academic writing. On the contrary, Johns (1997), Jordan (1997), Lee and Schallert (1997), Byrd and Reid (1998) and Zhou ( 2009) stressed on correlating between academic performance on writing and students grammar.

(Continue...) 


\section{Methodology}

\subsection{Participants}

The participants of this study include 10 male and female Iraqi ELF learners based on random sampling. They ranged from 25 to 33 years old. They were all native speakers of Iraqi language with the same language proficiency.

\subsection{Instruments \& Data Collection Procedure}

There were three research instruments in this study, a descriptive essay, a T-unit analysis, and a study analysis framework adapted from Dulay, Burt and Krashan (1982), Nangam's (2005) error taxonomy and Richard's (1971) error categories:

Dulay, Burt and Krashan's (1982) taxonomy was used in particular since it is expected to identify the language acquisition process that Iraqi students employ in their writing construction. Thereafter, the researcher started examining the source of errors generated within these writing essays. These sources are argued to be either from interlingual or intralingual source.

The descriptive essay on the topic was chosen as a data collection instrument because it related to the participants' interest and background, so it could motivate and enable them to write comfortably.

The T-unit was used as a data analysis instrument to analyze sentences in students' written essays ; its usage was to determine the sentences whether they consisted of a single unit of the sentence or more, and to identify those units whether they were a dependent clause or an independent clause.

Na-ngam's (2005) error taxonomy was employed to identify grammatical errors into types. It consisted of 23 types of grammatical errors: incomplete sentences (fragments and omissions), run-on sentences, comparison, word order, there-be, tenses, voices, agreements, infinitives and gerunds, nouns, verbs, adverbs, adjectives, pronouns, modals and auxiliaries, possessive's, conjunctions, prepositions, articles, punctuations, capitalization and spelling. 
Richards' (1971) error categories were manipulated to identify L1 interference errors. It originally consisted of ten types: omission of subject/verb/object/ complement, incorrect verb construction (serial verb construction), plural form of nouns, compound/ complex sentence structure, word order, "there" structure, fragment, run-on sentence, and word-byword translation. Since this study aimed at investigating grammatical errors and L1 interference errors, the above frameworks were then combined. However, there were six types of L1 interference errors in Richards' errors categories that overlapped with some of error types in Na-ngam's error taxonomy. According to T-unit analysis, moreover, there were two types of errors in the merged framework that could not be considered as grammatical errors, and they needed to be eliminated from the framework; they were capitalization errors and spelling errors. Therefore, the study analysis framework, then, consisted of 26 types of errors ; they were incomplete sentences (fragments and omissions), run-on sentences, comparison, word order, there-be, tenses, voices, agreements, infinitives, gerunds, nouns, verbs, adverbs, adjectives, pronouns, modals, auxiliaries, possessive's, conjunctions, prepositions, articles, punctuations, incorrect verb construction (serial verb construction), compound/ complex sentence, word by word translation and others (errors that was too complicated to be grouped).

In summary, among the 26 types of grammatical errors, there were 10 types of them were also considered as L1 interference errors. However, after this framework was tried out, four more types of L1 interference errors were added to the researcher's framework as they could be found in Iraqi students' written work. These four extra types of L1 interference errors were sub-types under some of the 26 types of grammatical errors. For more understandable, the four extra types of L1 interference errors were: 1) misuse of simple present tense for simple past tense (a sub-type of tenses), 2) subject-verb agreement (a subtype of agreement), 3) omission of auxiliary in negative sentences (a sub-type of verbs), and 4) omission of some punctuation marks (comma/ period/ question mark) (a sub-type of punctuations). Therefore, the adapted framework was then carrying 14 types of L1 interference errors. The interlingual sources are those caused by negative transfer or interference from the learners' mother tongue, while the intralingual sources are those caused by interference within the target language itself (Dulay et al. 1982). 


\subsection{Data Collection}

In order to analyze the data, the adapted framework for the current study was designed as follows:

Table 1 - The adapted framework for the current study

\begin{tabular}{|c|c|c|c|c|c|}
\hline Tense & $\begin{array}{l}\text { Prepositio } \\
\text { n }\end{array}$ & Articles & $\begin{array}{l}\text { Active \& } \\
\text { Passive } \\
\text { Voice }\end{array}$ & Verbs & $\begin{array}{l}\text { Morphologic } \\
\text { al } \\
\text { errors }\end{array}$ \\
\hline $\begin{array}{l}\quad \text { Past } \\
\text { perfect } \\
\text { instead of } \\
\text { simple } \\
\text { past }\end{array}$ & Omission & $\begin{array}{l}\text { Omissio } \\
\mathrm{n} \text { of "the" }\end{array}$ & $\begin{array}{c}\text { Passive } \\
\text { auxiliary Be } \\
\text { omission }\end{array}$ & $\begin{array}{c}\text { Omissio } \\
\text { n of verb } \\
\text { "be" }\end{array}$ & $\begin{array}{l}\text { Omission of } \\
\text { plural ending "s" }\end{array}$ \\
\hline $\begin{array}{l}\text { Present } \\
\text { progressiv } \\
\mathrm{e} \text { instead } \\
\text { of simple } \\
\text { present }\end{array}$ & Addition & $\begin{array}{l}\text { Addition } \\
\text { of "the" }\end{array}$ & $\begin{array}{c}\text { Passive } \\
\text { with } \\
\text { intransitive } \\
\text { verb Be } \\
\text { addition } \\
\end{array}$ & $\begin{array}{l}\text { Addition } \\
\text { of verb } \\
\text { "be" }\end{array}$ & $\begin{array}{l}\text { Misuse of } \\
\text { plural errors and } \\
\text { addition of the } \\
\text { plural ending " } \mathrm{s"} \text { " }\end{array}$ \\
\hline \begin{tabular}{l}
\multicolumn{1}{c|}{ Simple } \\
past \\
instead of \\
simple \\
present
\end{tabular} & Misuse & $\begin{array}{r}\text { Omissio } \\
\mathrm{n} \text { of "a/an" }\end{array}$ & $\begin{array}{l}\text { Prepositio } \\
\mathrm{n} \text { confusion }\end{array}$ & $\begin{array}{l}\text { Misuse } \\
\text { of the verb } \\
\text { "be" }\end{array}$ & $\begin{array}{c}\text { Misuse of } \\
\text { possessive "s" }\end{array}$ \\
\hline \begin{tabular}{l}
\multicolumn{1}{c}{ Simple } \\
present \\
instead of \\
present \\
perfect
\end{tabular} & & $\begin{array}{l}\text { Addition } \\
\text { of "a/an" }\end{array}$ & & $\begin{array}{l}\text { Omissio } \\
\mathrm{n} \text { of the } \\
\text { verbs }\end{array}$ & $\begin{array}{l}\text { Incorrect use } \\
\text { of comparative } \\
\text { adjectives }\end{array}$ \\
\hline \begin{tabular}{l}
\multicolumn{1}{c}{ Simple } \\
past \\
instead of \\
present \\
perfect
\end{tabular} & & $\begin{array}{r}\text { Misuse } \\
\text { of articles }\end{array}$ & & $\begin{array}{l}\text { Misuse } \\
\text { of other } \\
\text { verbs }\end{array}$ & $\begin{array}{l}\text { Wrong word } \\
\text { form }\end{array}$ \\
\hline
\end{tabular}

(Continue...) 


\section{Results}

\subsection{Data Analysis}

Overall, 352 grammatical errors were found in both groups of male and female learners. To find out the answer to the first research question the errors were analyzed based the adapted framework. Table 2 presents the results.

Table 2 - Frequency and percentage of the committed errors

\begin{tabular}{c|c|c|c|c|c|c|c}
\hline & Tense & Preposition & Articles & $\begin{array}{c}\text { Active\& } \\
\text { Passive } \\
\text { Voice }\end{array}$ & Verbs & $\begin{array}{c}\text { Morphological } \\
\text { errors }\end{array}$ & \\
\hline Frequency & 53 & 48 & 59 & 56 & 65 & 71 & 352 \\
\hline Percentage & $12 \%$ & $11 \%$ & $14 \%$ & $13 \%$ & $22 \%$ & $28 \%$ & 100 \\
\hline
\end{tabular}

According to Table 2, the most commonly errors committed by EFL Iraqi learners include morphological errors $(71,28 \%)$, verbs $(65,22 \%)$, articles $(59,14 \%)$, active and passive $(56,13 \%)$, tense $(53,12 \%)$, and preposition $(48,11 \%)$, respectively. In addition, the committed errors by the male and female were calculated separately and compared via independent samples t-test. Table 3 illustrates the results.

Table 3 - One Sample T-Test for Iraqi male and female groups

\begin{tabular}{|c|c|c|c|c|c|c|c|c|c|}
\hline \multirow{3}{*}{$\begin{array}{c}\text { Levene's } \\
\text { Test for } \\
\text { Equality } \\
\text { of } \\
\text { Variances }\end{array}$} & \multicolumn{9}{|c|}{ t-test for Equality of Means } \\
\hline & \multirow[t]{2}{*}{$\mathbf{F}$} & \multirow[t]{2}{*}{ Sig. } & \multirow[t]{2}{*}{$\mathbf{t}$} & \multirow[t]{2}{*}{ df } & \multirow[t]{2}{*}{$\begin{array}{l}\text { Sig.(- } \\
\text { tailed) }\end{array}$} & \multirow[t]{2}{*}{$\begin{array}{c}\text { Mean } \\
\text { Difference }\end{array}$} & \multirow[t]{2}{*}{$\begin{array}{l}\text { Std. Error } \\
\text { Difference }\end{array}$} & \multicolumn{2}{|c|}{$\begin{array}{c}95 \% \\
\text { Confidence } \\
\text { Interval of } \\
\text { the } \\
\text { Difference }\end{array}$} \\
\hline & & & & & & & & Lower & Upper \\
\hline $\begin{array}{l}\text { Equal } \\
\text { variances } \\
\text { assumed }\end{array}$ & 2.583 & .111 & 1.436 & 9 & .154 & 1.233 & .859 & -.467 & 2.934 \\
\hline
\end{tabular}




\begin{tabular}{|c|c|c|c|c|c|c|c|}
\hline $\begin{array}{l}\text { Equal } \\
\text { variances } \\
\text { not } \\
\text { assumed }\end{array}$ & 1.436 & 111.833 & .154 & 1.233 & .859 & -.468 & 2.935 \\
\hline
\end{tabular}

As shown in Table 3, due to the fact that Levene's Test result is not significant(p> 0.05)the equal variances assumed was considered. In t-test for equality of means, since $p<$ 0.154 is more than the significance level $\alpha=0.05$, and therefore, it is concluded that the mean two groups is not significantly different.

\section{Discussion}

The current study was set to investigate the common grammatical errors among Iraqi male and female EFL learners in the written discourse. The findings revealed that the common grammatical errors consisted of morphological errors, verbs, articles, active and passive, tense, and preposition, respectively. In addition, the current study explored the difference between the male and female Iraqi EFL learners in terms of the grammatical errors in written discourse. The findings indicated that no difference was found in male and female groups. The findngs can be attributed to the fact that interference from L1 and inadequate components of L2 are the main source of errors. These results are argued to be very essential in learning the target language since the sources of errors within the context of this study were identified so that remedial teaching design can be easily prepared depend on these results generated.

Studying the nature of errors enables teachers of foreign languages and researchers to have a better understanding of the linguistic area where learners have the most difficulty while writing. The data provided by the analysis of learners' errors might help teachers, syllabus designers and test developers to determine their way of teaching or materials in the process of language teaching and learning. They should make use of such studies to acquire new techniques and insights. It is possible for them to see language learners from a different point of view.

The results of the study indicated that the Iraqi students learners are competent in basic rules of the target language, but their knowledge of the target language has some 
defects. These defects in Learning the target language may be due to the lack of practice in writing during their education level at schools in Iraqi or during their degree level. Accordingly, teachers of foreign languages should focus on the most common errors and try to overcome them by using various materials and methods. They can conduct remedial teaching using exercises and skills related to the problematic areas of the target language. Besides, textbook designers and syllabus designers should design their materials in the light of these errors. Test developers should also construct their tests according to these errors so that they could measure students' improvement by proper tests.

\section{Conclusion}

Regarding the types of errors found in the grammatical categories, intralanguage interference (interference within the target language) was found to be the most dominant cause of errors in students' written work. This means that Iraqi learners lack concrete grammatical knowledge of the target language. Further studies may consider comparing EFL learners regarding the errors they make in their writing. Knowing the similarities and the differences between two groups through error analysis would tell us a lot about students' learning process. Three possible pedagogical implications could be drawn from this study. First, committing errors is a part of language learning process. Thus, students' errors can be considered as valuable resources to improve teaching and learning in writing classrooms. Students' attempt in trying to write ought to be praised and teachers must motivate their students to write in order to apply the correct grammatical form in their writing. Second, for specific instructional activities for verb tense, explicit instruction in each linguistic feature should be included in the classroom. Teachers can provide collaborative teaching technique for practicing different tenses in different contexts. Third, most of the grammatical errors found were from the lack of knowledge of the target language, which may indicate that students have not received sufficient input in their writing instructions. Therefore, English language teachers ought to be trained in using various innovative teaching methods and techniques in the class to help students fully understand the English language system. 


\section{Reference}

Abushihab, I., El-Omari, A.H \& Tobat, M. (2011). An Analysis of Written Grammatical Errors of Arab Learners of English as a Foreign Language at Alzaytoonah Private University of Jordan. European Journal of Social Sciences, 20(4), 12-23.

Al-Bayati, W. A.W.T. (2013). Errors Made By Iraqi EFL Undergradute in The Use of Prepositions. Bulletin of the Transilvania University of Braşov Series IV: Philology and Cultural Studies, 6 (5), 32-49.

Al-Buainain, H. (2010). RESEARCHING TYPES AND CAUSES OF ERRORS IN ARABIC SPEAKERS' WRITINGS. Arab World English Journal, 12, 34- 52.

Alavi, M. \& Mansor, S.M.S. (2011). Categories of problems among international students in Universiti Teknologi Malaysia. Procedia Social and Behavioral science. 1581-1587.

Bacha, N.N. (2002).Developing Learners' Academic Writing Skills in Higher Education: A Study for Educational Reform. Language \& Education, 1(3), 161-177.

Chan, A.Y.W (2004). Syntactic Transfer: Evidence from the Interlanguage of Hong Kong Chinese ESL learners, Modern language Journal. 8(4), 56-74.

Corder ,S. P. (1981). Error Analysis and Interlanguage. Oxford University Press, Oxford.

Corder, S. (1967).The significance of learners' errors. International Review of Applied Linguistics, 5(4), 161-169.

Corder, S. P. (1973). Introducing Applied Linguistics. London. Penguin Books. p. 265.

Crompton, P. (2011). Articles Errors in the English writing of Advanced L1 Arabic Learners: The Role of Transfer. Asian EFL Journal. Professional Teaching Articles, 5(3), 50-66.

Crystal, D. (2003). The Cambridge Encyclopedia of the English Language. 2nd Edition. Cambridge. Cambridge University Press.

Dulay, H., Burt, M. \& Krashen, S.D: (1982). Language Two. Oxford University Press, Oxford.

Kharma, N. \& Hajjaj, A. (1997). Errors in English among Arabic speakers. Beirut: Librairie du Liban.

Rababah, G. (2003). Communication Problems Facing Arab Learners of English: A personal Perspective. In: TEFL web journal, 2(1), 15-27.

Schulz, E. (2004). A student Grammar of Modern Standard Arabic. Cambridge: Cambridge University press.

Tushyeh, (2010). Problems facing Arab Learners of English. ITL Review of Applied 
Linguistics, 4(3), 109-117.

Yahya, B. (2007). Identifying the advanced Iraqi EFL leaners' Obstacle in Comprehension live speech and their pedagogical implications, 4, 55-72. 